\title{
Phytoliths as a Tool for the Identification of Some Chloridoideae Grasses in Kerala
}

\author{
P. I. Jattisha and M. Sabu \\ Department of Botany, University of Calicut, Kerala 673 635, India \\ Correspondence should be addressed to P. I. Jattisha, jattisha.p@gmail.com
}

Received 15 October 2012; Accepted 18 November 2012

Academic Editors: T. Berberich, F. A. Culianez-Macia, and S.-W. Park

Copyright ( $) 2012$ P. I. Jattisha and M. Sabu. This is an open access article distributed under the Creative Commons Attribution License, which permits unrestricted use, distribution, and reproduction in any medium, provided the original work is properly cited.

The phytoliths of eight genera including fifteen species of grasses under the subfamily Chloridoideae in Kerala were studied. Phytoliths were studied after chemical isolation. Every species was found to produce a diverse array of phytoliths. However the frequency assemblages of phytoliths, their size, and orientation in the epidermal layer appear to vary among the different species and hence can be used for the delimitation of the taxa. Consequently, an identification key following the International Code for Phytolith Nomenclature was developed for all the species studied.

\section{Introduction}

Silicon is deposited in plants as hydrated amorphous silica $\left(\mathrm{SiO}_{2} \cdot n \mathrm{H}_{2} \mathrm{O}\right)$ through the polymerization of monosilicic acid $\left(\mathrm{Si}(\mathrm{OH})_{4}\right)$ absorbed by roots from soil [1]. Silica deposited as inclusions within the cells are usually termed as phytoliths or silica bodies. Phytoliths have proved to be a potential tool in palaeoecological studies as they remain stable in the soil for even millions of years after plant tissues decay [2-12].

Depending upon the species of the plant, silica is deposited between the cells, within the cell walls, or even sometimes completely infilling the cells themselves. Silica bodies in the silica cells of grasses assume characteristic forms when the leaf is mature. Silica deposits in grasses have been well documented [13-17]. According to Metcalfe and Kaufman et al. [13, 18] silica deposits in grasses occur primarily in epidermal long cells, trichomes (hairs), specialized silica short cells, and as fillings within the bulliform cells of plant leaves. Phytolith shapes are found to be consistent within a species and hence they can provide significant taxonomic information [6, 19-21].

Metcalfe [13] considered the structure of silica bodies as one of the characteristics useful in plant identification. Since the publication of Metcalfe's work, the utility of phytoliths in plant taxonomy has been demonstrated in other publications. Studies made by Ollendorf et al. [14] have shown that phytolith characters can be used to distinguish Arundo donax from Phragmites communis, two giant reed grasses that is otherwise difficult to identify from the field. Various studies have been made to distinguish phytoliths in cultivated crops from those of wild relatives of crop plants [22-24].

The present study is concerned with the identification of some Chloridoideae grasses in the vegetative stage based on the size, shape, frequency, and orientation of phytoliths in the leaf epidermis.

\section{Materials and Methods}

Plants included in the present study belong to the subfamily Chloridoideae of the family Poaceae, according to the classification made by Clayton and Renvoize [25]. In particular, a total of fifteen species of grasses under eight genera were selected for the present study (Table 1). Specimens were collected fresh from different parts of Kerala. Voucher specimens of collected plants are deposited in Calicut University Herbarium (CALI). Herbarium specimens collected from CALI were also utilized for the study.

Mature leaf blades were selected for the present study. The leaf blades were first washed in water and wiped dry. They were then cut into $1 \mathrm{~cm}^{2}$ pieces and soaked in acid mixture (con. $\mathrm{HNO}_{3}+$ con. $\mathrm{H}_{2} \mathrm{SO}_{4}$ in $1: 1$ proportion) for 15 days [15]. The mixture was then centrifuged and the 
TABLE 1: Grasses included in the present study.

\begin{tabular}{llc}
\hline Si. no. & Latin name & Collection no. \\
\hline$(1)$ & Chloris barbata Sw. & $127309,127380,6177$ \\
$(2)$ & Cynadon arcuatus J.S. Presl. ex C.B. Presl. & 127304 \\
$(3)$ & C. dactylon (Linn.) Pers. & 113370,11276 \\
$(4)$ & Dactyloctenium aegyptium (Linn.) P. Beauv. & $113373,8951,3580$ \\
$(5)$ & Eleusine corocana (Linn.) Gaertn. & $124901,521,3819$ \\
$(6)$ & E. indica (Linn.) Gaertn. & $113343,9479,2667$ \\
$(7)$ & Eragrostis nutans (Retz.) Steud. & 127390 \\
$(8)$ & E. tenella (Linn.) Roem. and Schult & 113375,34419 \\
$(9)$ & E. unioloides (Retz.) Steud. & $113383,3587,2565$ \\
$(10)$ & E. viscosa (Retz.) Trin. & 113351,12406 \\
$(11)$ & Leptochloa chinensis (Linn.) Nees & 127355 \\
$(12)$ & Perotis indica (Linn.) O. Kuntze & $113381,5803,3986$ \\
$(13)$ & Sporobolus diander (Retz.) P. Beauv. & 113377,1337 \\
$(14)$ & S. piliferus (Trin.) Kunth & $127307,2891,4650$ \\
$(15)$ & S. tenuissimus (Schrank) O. Kuntze & 113357,113375 \\
\hline
\end{tabular}

TABLE 2: Different types of phytoliths observed and their abbreviations.

\begin{tabular}{llc}
\hline Si. no. & Type & Abbreviation \\
\hline$(1)$ & Associated epidermal polygonal cells & AEP \\
$(2)$ & Associated long cells & ALC \\
$(3)$ & Associated papilla & AP \\
$(4)$ & Associated short cells & AS \\
$(5)$ & Bulliform elements & BE \\
$(6)$ & Stomatal complex & SC \\
$(7)$ & Subepidermal elements & SEE \\
$(8)$ & Simple bilobate & SB \\
$(9)$ & Complex bilobate & CB \\
$(10)$ & Nodular bilobate & NB \\
$(11)$ & Quadralobate & Q \\
$(12)$ & Normal saddle & S \\
$(13)$ & Elongate & E \\
$(14)$ & Fan & F \\
$(15)$ & Horned towers & HT \\
$(16)$ & Macrohairs & LH \\
$(17)$ & Microhairs & MH \\
$(18)$ & Prickle hairs & PR \\
$(19)$ & Papilla & P \\
\hline
\end{tabular}

Abbreviations for lobate phytoliths are followed by C, F, or X denoting concave, fattened, or convex margins.

acid decanted. The residue was then suspended in distilled water and again centrifuged. This process was repeated upto 4 cycles inorder to completely remove the acid from the residue. The final residue was then suspended in rectified spirit and stored in storage vials for further study.

A drop of the phytolith alcohol mixture was placed on a clean slide and warmed under the spirit lamp. Then a drop of crystal violet stain was applied and again warmed. Excess stain was removed by suddenly dipping the slide and taking out from water. This was warmed again and the slide was mounted permanently in DPX (Distyrene Plasticizer Xylene) for further observations and photography.

For observations and photography Motic Digital Microscope with image analyser was used. Observations and photography were taken under oil immersion objective (100x). Measurements were taken from surface view of phytoliths using Motic Image Analyzer software. Various features of phytoliths noted include length, width, nature of outer margins, shape, and so forth.

In addition to measurement, frequency of phytolith assemblages was also noted. About 1000 phytoliths from each species were counted and frequency determined. For both frequency and measurement range, average and standard error were calculated.

Photographs of different types of phytoliths observed for different species are also provided. Species taken for the present study and their collection number are shown in Table 1. The serial numbers of the species shown in this table are used to denote the name of the species in Tables 3 and 4 .

\section{Results}

Data obtained from the frequency of phytolith assemblages as well as measurements were utilized for the preparation of an identification key for grasses upto species level. Length and width dimensions and frequency of about 1000 phytoliths were measured from each species. The present study on phytoliths applies the rules of International Code for Phytolith Nomenclature [26]. Silica bodies were found in two forms-articulated (associated with other cells) and isolated. Various types of phytoliths observed and their abbreviations used are given in Table 2 .

3.1. Articulated Forms. These are the associated forms of phytoliths found joined either with the same type or different types of cells. These include the following subcategories. 


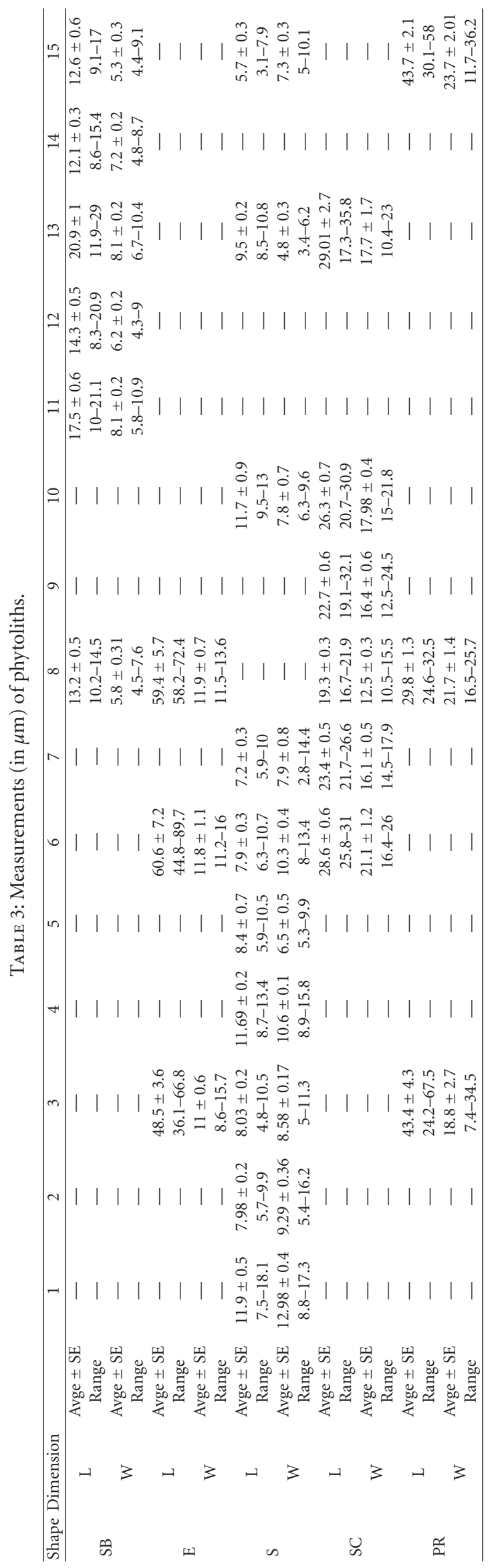




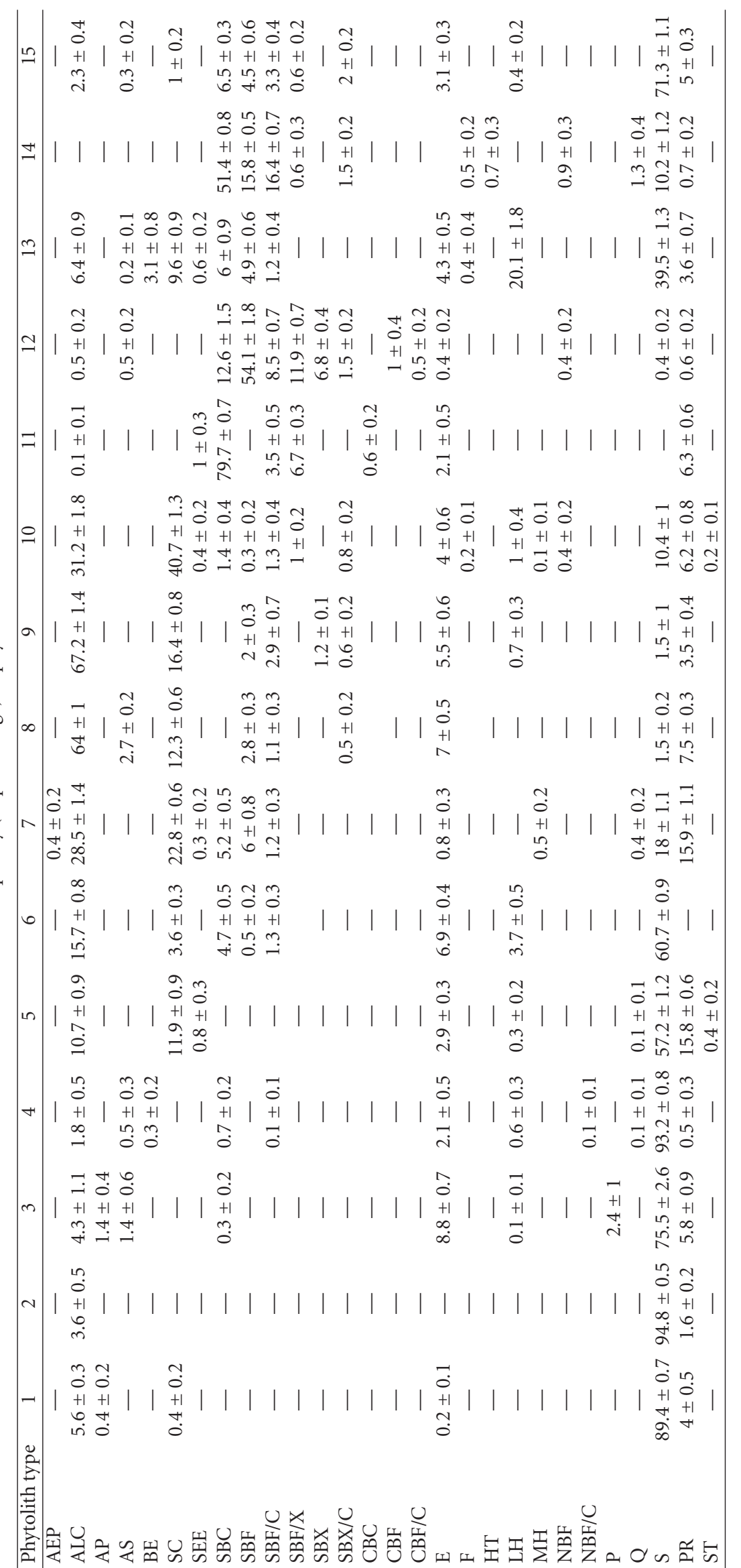




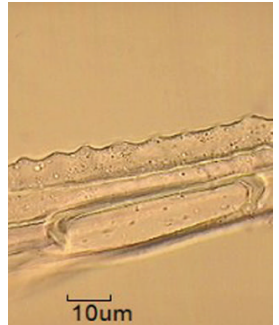

(1a)

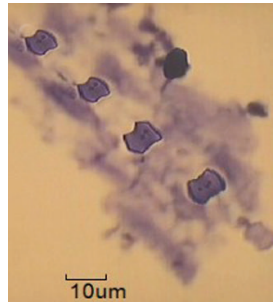

(2a)

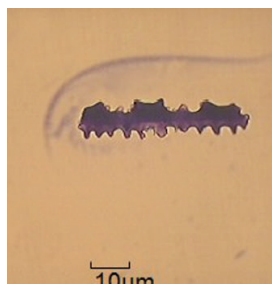

(4a)

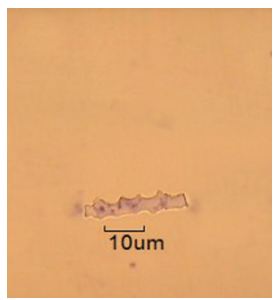

(4f)

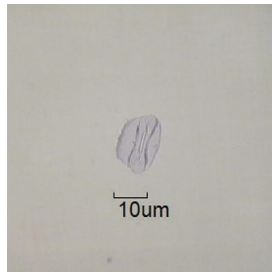

(5c)

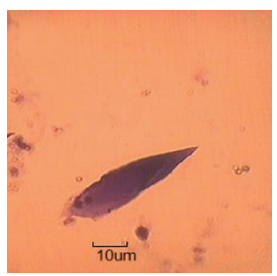

(8b)

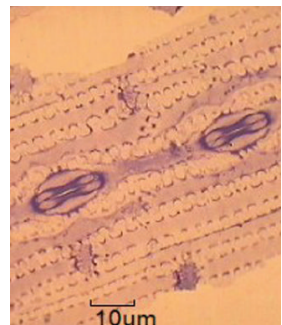

(1b)

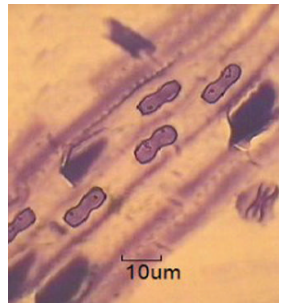

(2b)

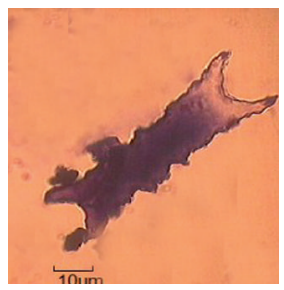

(4b)

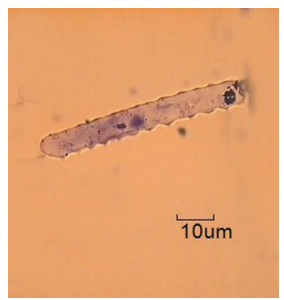

(4g)

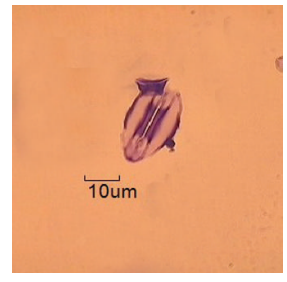

(5d)

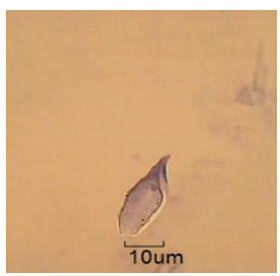

(8c)

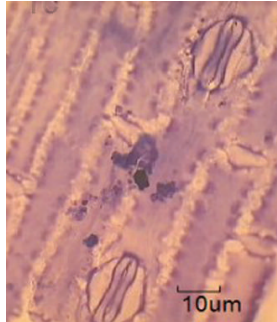

(1c)

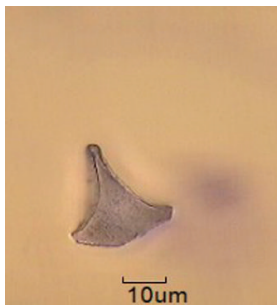

(3a)

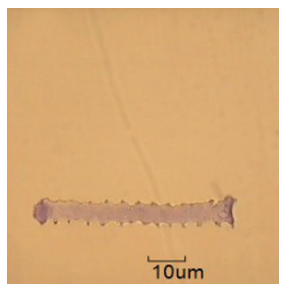

(4c)

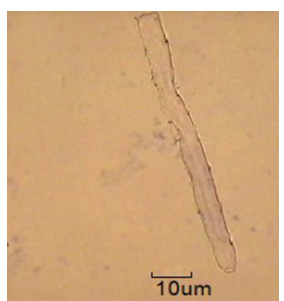

(4h)

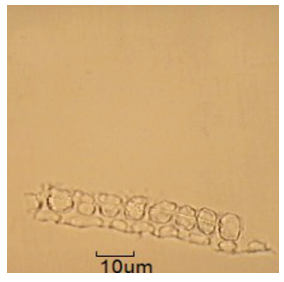

(6a)

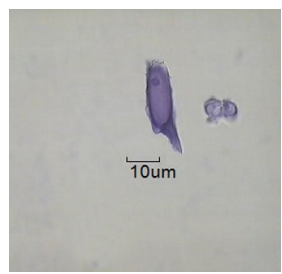

(8d)

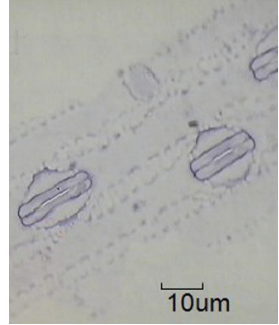

(1d)

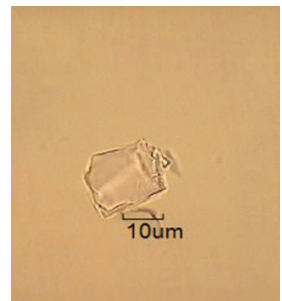

(3b)

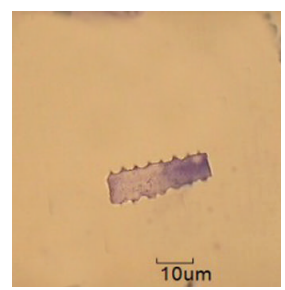

(4d)

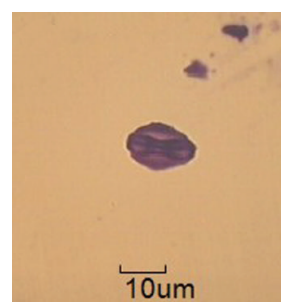

(5a)

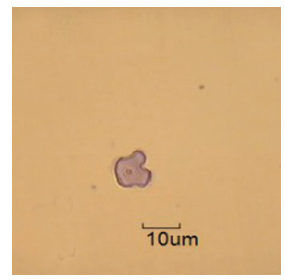

(7a)

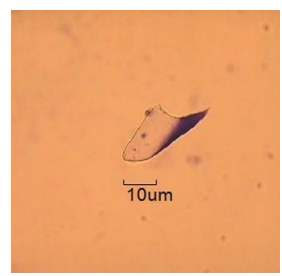

(8e)

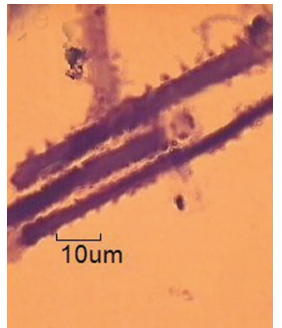

(1e)

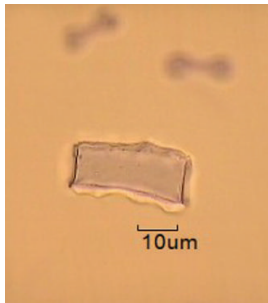

(3c)

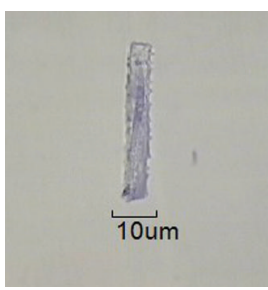

(4e)

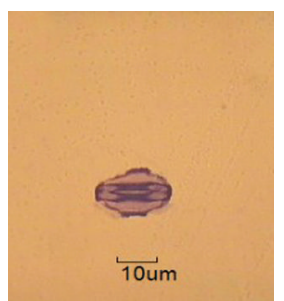

(5b)

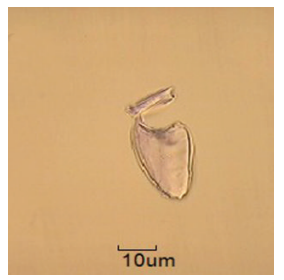

(8a)

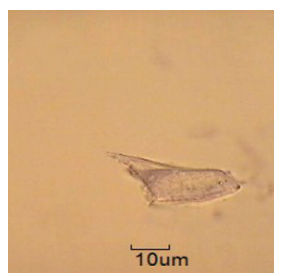

(8f)

Figure 1: Associated long cells of (1a) Dactyloctenium aegyptium, (1b) Eragrostis tenella, (1c) E. unioloides, (1d) E. viscosa, (1e) Sporobolus diander; (2) associated short cells of (2a) Cynadon arcuatus, (2b) Eragrostis tenella; (3) fan cells of (3a) Cynadon arcuatus, (3b) C. dactylon, (3c) Perotis indica; (4) elongate cells of (4a) Cynadon dactylon, (4b) Eleusine corocana, (4c) Eragrostis tenella, (4d) E. unoloides, (4e) E. viscosa, (4f) Perotis indica, (4g) Sporobolus diander, (4h) S. tenuissimus; (5) stomatal complex of (5a) Cynadon dactylon, (5b), (5c) E. viscosa, (5d) Sporobolus diander; (6) (6a) subepidermal elements of Dactyloctenium aegyptium; (7) (7a) horned tower of Sporobolus piliferus (8) prickle hairs of (8a) Dactyloctenium aegyptium, (8b) Eleusine corocana, (8c) Eragrostis tenella, (8d) E. viscosa, (8e) Sporobolus tenuissimus, (8f) S. diander. 


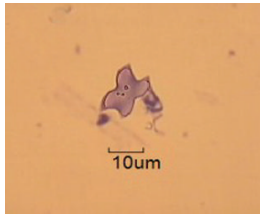

(1a)

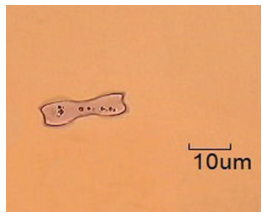

(1f)

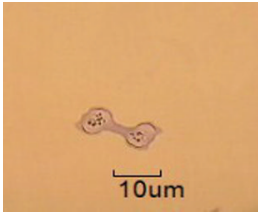

(2c)

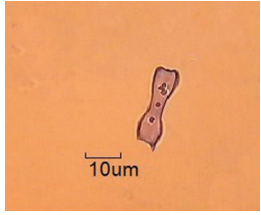

(3c)

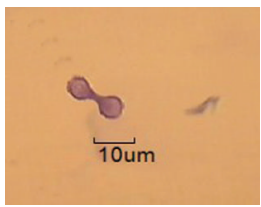

(5a)

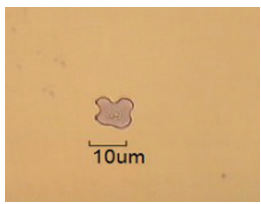

(10a)

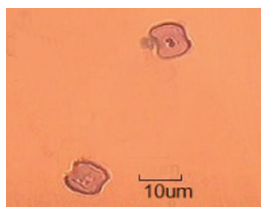

(11e)

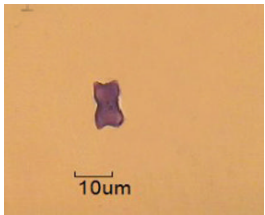

(1b)

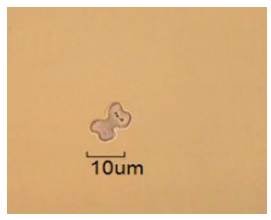

(1g)

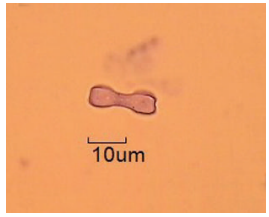

(2d)

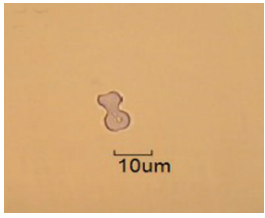

(3d)

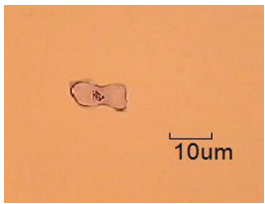

(6a)

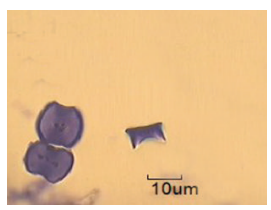

(11a)

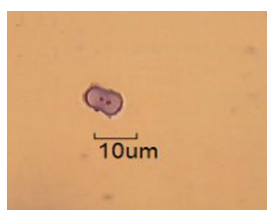

(11f)

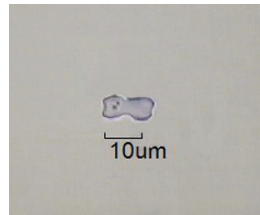

(1c)

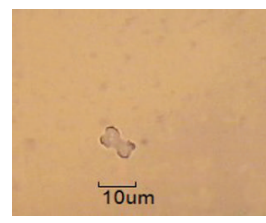

(1h)

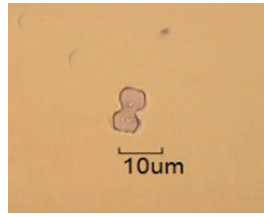

(2e)

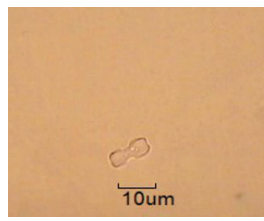

(3e)

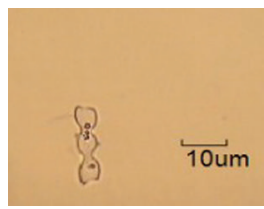

(7a)

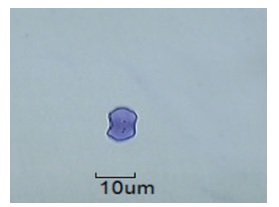

(11b)

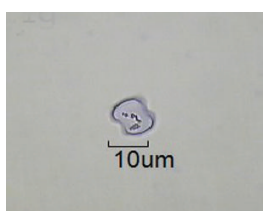

(11g)

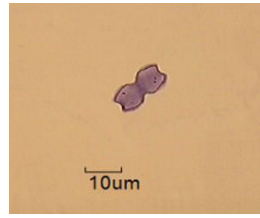

(1d)

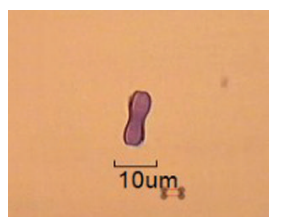

(2a)

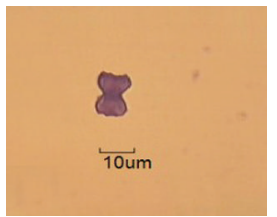

(3a)

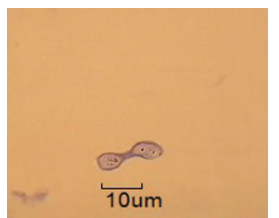

(4a)

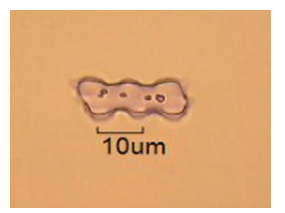

(8a)

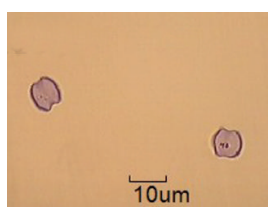

(11c)

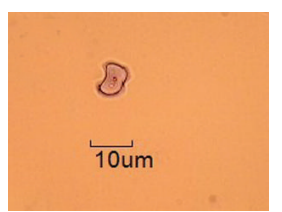

(11h)

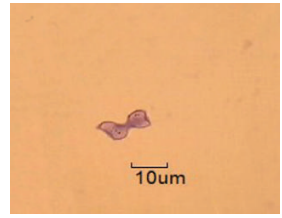

(1e)

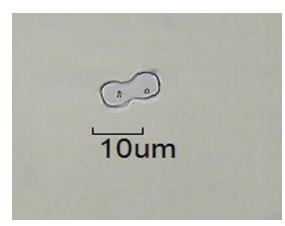

(2b)

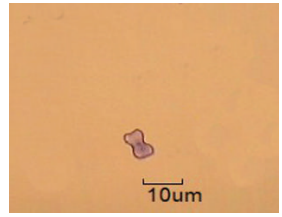

(3b)

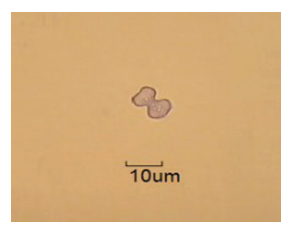

(4b)

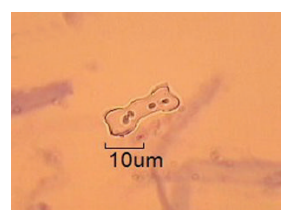

(9a)

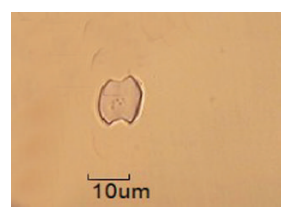

(11d)

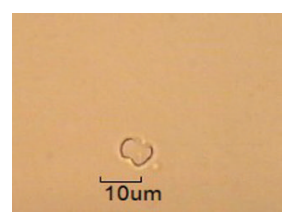

(11i)

Figure 2: 1-6: Simple bilobates (1) Bilobate with concave margins. (1a) Eleusine indica, (1b) Eragrostis tenella, (1c) E. viscosa, (1d) Leptochloa chinensis, (1e) Perotis indica, (1f) Sporobolus diander (1g) S. piliferus (1h) S. tenuissimus; (2) bilobate with flattened margins. (2a) Eragrostis tenella, (2b) E. viscosa, (2c) Perotis indica, (2d) Sporobolus diander, (e) S. piliferus; (3) bilobate with flattened/concave margins. (3a) Eleusine indica, (3b) Perotis indica, (3c) Sporobolus diander, (3d) S. piliferus, (3e) S. tenuissimus; (4) Bilobate with flattened/concex margins. (4a) Perotis indica, (4b) Sporobolus piliferus; (5) (5a) Bilobate with convex margins of Perotis indica; (6) (6a) Bilobate with convex/concave margins of Sporobolus diander; (7) (7a) complex bilobate with concave margins of S. piliferus; (8) (8a) Complex bilobate with flattened margins of Eleusine indica; (9) (9a) nodular bilobate with concave margins of Sporobolus diander; (10) (10a) quadralobate phytoliths of S. piliferus; (11) saddles. (11a) Chloris barbata, (11b) Cynadon arcuatus, (11c) C. dactylon (11d) Dactyloctenium aegyptium (11e) Eleusine corocana (11f) E. indica, (11g) Eragrostis viscosa, (11h) S. diander, (11i) S. tenuissimus. 
(1) Associated Epidermal Polygonal Cells. Polygonal shaped cells of the epidermal cells with smooth or sinuate margins. These were observed only in Eragrostis nutans with a frequency below $1 \%$.

(2) Associated Long Cells. These are associated long cells of the epidermis either with stomata or prickle hairs. These are very common and are found in almost all the species. Their frequency in Eragrostis unioloides is greater than 60\%.

(3) Associated Papilla. These are protrusions from the epidermal cells. Sometimes 2 or more papillae are seen associated together. These were observed only in Chloris barbata and Cynadon dactylon with a frequency less than $2 \%$.

(4) Associated Short cells. These are long cells associated with one or more short cells. Frequency of this type was found to be always less than $3 \%$. However they were observed in six species.

(5) Bulliform Elements. These are silicified bulliform cells associated with each other. These were observed only in two species, that is, Dactyloctenium aegyptium and Sporobolus diander, with a frequency below $4 \%$.

(6) Stomatal Complex. These are silicified guard cells joined together. This is a common type and were observed in nine species studied. The highest frequency of about $40 \%$ was observed in Eragrostis viscosa.

(7) Subepidermal Elements. These are silicified mesophyll or other cells present beneath the epidermis. These were observed in five species but their frequency was less than $1 \%$.

3.2. Isolated Forms. Phytoliths remain isolated without association with other cells. These include the following.

(8) Simple Bilobate. These are phytoliths with two equal lobes connected by a shank. Their margins can be concave, convex or flattened or the two lobes of the same phytolith can have different margins. At least one type of simple bilobate phytoliths is represented in all the species except Chloris barbata and Cynadon arcuatus where they were found to be totally absent.

(9) Complex Bilobate. These are phytoliths with 3 equal lobes. Their margins may be concave or flattened. This is a rare type in the subfamily and their frequency falls below $2 \%$. They were observed only in Leptochloa chinensis and Perotis indica.

(10) Nodular Bilobate. These are bilobate phytoliths with a projection or a small lobe between the two major lobes. Margins can be concave or flattened. Convex margins are found to be totally absent in the subfamily.
(11) Quadralobate. They are characterised by almost similar length and width dimensions and in having four lobes. They were observed only in four species with a frequency of less than $2 \%$.

(12) Normal Saddle. Saddle shaped phytoliths are arranged vertically on the epidermis. They are present in almost all the members of Chloridoideae except one, that is, Leptochloa chinensis.

(13) Elongate. These are silicified long cells of the epidermis with echinate or sinuate walls. They are represented in all the species except two. However their frequency does not exceed beyond $10 \%$. The highest frequency of $8.8 \%$ was observed in Cynadon dactylon.

(14) Fan. These are silicified bulliform cells of the epidermis. They were found in Eragrostis viscosa, Sporobolus diander and S. piliferus with a frequency less than $1 \%$.

(15) Horned Towers. Cylindrical short cells with two projections on one side. This type was observed only in Sporobolus piliferus with a frequency of $0.7 \%$.

(16) Macro Hairs. These are elongated hairs present on the epidermis. They were observed in eight species studied. Their frequency in most cases falls below 5\%. However in Sporobolus diander it is $20 \%$.

(17) Microhairs. These are formed as a result of silicification of slightly curved two-celled blunt hairs of the epidermis. This type is rare and was observed in Eragrostis nutans and E. viscosa. Their frequency is less than $1 \%$.

(18) Prickle Hairs. These are formed as a result of silicification of sharply pointed and slightly curved structures on the epidermis. This is a common type found in all the species except Eleusine indica. Highest frequency of about $15 \%$ was observed in Eleusine corocana and Eragrostis nutans.

(19) Papilla. Protrusions from the epidermis seen isolated. This is very rare in the subfamily and was observed only in Cynadon arcuatus with a frequency of $2.4 \%$.

All the dimensions of phytoliths were studied. For taking measurements surface view of phytoliths were considered. Measurements of phytoliths of each species are shown in Table 3. and frequency assemblages in Table 4. Photographs of different types of phytoliths are given in Figures 1 and 2.

Key for the identification of species based on the frequency, size, and shape of phytoliths.

\section{Key to the Species}

(1) Saddles less than 1\%, simple bilobates dominant with a frequency of $90-96 \% \ldots 2$.

(1) Saddles greater than $1 \%$, simple bilobates usually not dominant, if so, frequency below $80 \% \ldots 3$. 
(2) Simple bilobates with concave margins dominant with frequency greater than $70 \%$...Leptochloa chinensis.

(2) Simple bilobates with flattened margins dominant with frequency less than $50 \%$...Perotis indica.

(3) Saddles the most dominant type, simple bilobate phytoliths rare, if present only less than $1 \% \ldots 4$.

(3) Saddles usually not the most dominant type, if so simple bilobates $5 \%$ or greater. .. 8 .

(4) Average length of saddles 11-12 $\mu \mathrm{m} . .5$.

(4) Average length of saddles 7-9 $\mu \mathrm{m} . . .6$.

(5) Hook shaped prickles present, average width of saddles about $10.6 \mu \mathrm{m}$...Dactyloctenium aegyptium.

(5) Hook shaped prickles absent, straight sharply pointed structures seen, average width of saddles about $12.9 \mu \mathrm{m}$...Chloris barbata.

(6) Saddles constitute about greater than $75 \%$ of the total phytoliths...7.

(6) Saddles constitute less than $60 \%$ of the total phytoliths. .. Eleusine corocana.

(7) Sharply pointed structures rare, less than $2 \%$ saddles about 95\% ....Cynadon arcuatus.

(7) Sharply pointed structures present at about 5\%, saddles about 76\% ...Cynadon dactylon.

(8) ALC and SC together constitute more than 50\% of the total phytoliths...9.

(8) ALC and SC usually very less and will not exceed $20 \%$...12.

(9) Average length of SC about $26 \mu \mathrm{m}$. . .Eragrostis viscosa.

(9) Average length of SC less than $25 \mu \mathrm{m} . . .10$.

(10) Proportion of ALC and SC nearly $1: 1 \ldots$ Eragrostis nutans.

(10) Proportion of ALC and SC is about $4: 1 \ldots 11$.

(11) SC about $12.5 \mu \mathrm{m}$ wide, outline more or less rounded...Eragrostis tenella.

(11) SC about $16 \mu \mathrm{m}$ wide, outline somewhat V-shaped, not rounded. ..Eragrostis unioloides.

(12) Frequency of saddle shaped phytoliths greater than $60 \% \ldots 13$.

(12) Frequency of saddle shaped phytoliths less than $50 \% \ldots 14$.

(13) ALC and SC together constitute more than 15\% of the total phytoliths. ..Eleusine indica.

(13) ALC and SC together constitute less than 5\% of the total phytoliths...Sporobolus tenuissimus.

(14) Frequency of simple bilobate phytoliths greater than $65 \%$, average width about $12.09 \mu \mathrm{m}$...Sporobolus piliferus.
(14) Frequency of simple bilobate phytoliths less than $15 \%$, average width about $20.9 \mu \mathrm{m}$. . Sporobolus diander.

\section{Discussion}

The present study of grasses from the Indian subcontinent underscores what previous investigations have shown already elsewhere-the Poaceae family produces a diverse array of phytolith shapes yet certain shapes of phytoliths can consistently appear at least at the subfamily level.

Saddle shaped phytoliths characterises the subfamily Chloridoideae. Of the 15 species studied saddle shaped phytoliths were found to be the dominant type in seven species. Saddles were not observed only in Leptochloa chinensis. Highest frequency of saddles was noticed in Chloris barbata, Cynadon arcuatus, Cynadon dactylon, and Dactyloctenium aegyptium. In Leptochloa chinensis, Perotis indica, and Sporobolus piliferus bilobate phytoliths were found to be the dominant type. Associated long cells and stomatal complex were found in almost all the species studied. However their frequency was found to supersede in species of Eragrostis. More species has to be studied before this character could be attributed as diagnostic to the genus.

Frequency of phytolith assemblages and measurements of phytoliths are found to be consistent within a species and have been useful for developing the key. Even though phytolith multiplicity and redundancy occur in grasses, frequency assemblages reveal that a particular morphotype dominate over the other in a given species. Hence the present study shows that characteristics of phytoliths can be used as a tool for the identification of the species in the vegetative stage.

A brief survey on 15 species of Chloridoideae grasses has proved the usefulness of phytoliths in the identification of grasses. The present paper represents only a preliminary study towards developing an identification key for all South Indian grasses based on the foliar phytolith characteristics.

\section{Acknowledgments}

Thanks are due to Department of Science and Technology (DST) for providing the Women Scientist Scheme Project (Order no. SR/WOS-A/LS-238/2009 dated 06.09.2010). The authors also thank Dr. A. K. Pradeep, Herbarium Curator, CALI, for providing the specimens needed for the present study.

\section{References}

[1] L. H. P. Jones and K. A. Handreck, "Silica in soils, plants, and animals," Advances in Agronomy, vol. 19, pp. 107-149, 1967.

[2] E. Blackman, "Opaline silica in the range grasses of southern Alberta," Canadian Journal of Botany, vol. 49, pp. 769-781, 1971.

[3] I. Rovner, "Plant opal-phytolith analysis. Major advances in archaeobotanical research," in Advances in Archaeological Method and Theory, M. Schiffer, Ed., vol. 6, Academic Press, New York, NY, USA, 1983. 
[4] J. Bartolome, S. E. Klukkert, and W. J. Barry, "Opal phytoliths as evidence for displacement of native Californian grassland," Madrono, vol. 33, pp. 217-222, 1986.

[5] P. C. Twiss, "Grass-opal phytoliths as climatic indicators of the Great Plains Pleistocene," in Quarternary Environments of Kansas, W. C. Johnson, Ed., pp. 179-188, Kansas Geological Survey, Lawrence, Kan, USA, 1987.

[6] D. Piperno, Phytolith Analysis : An Archaeological and Geological Perspective, Academic Press, New York, NY, USA, 1988.

[7] R. F. Fisher, C. N. Bourn, and W. F. Fisher, "Opal phytoliths as an indicator of the floristics of prehistoric grasslands," Geoderma, vol. 68, no. 4, pp. 243-255, 1995.

[8] A. J. Alexandre, D. Meunier, A. M. Lézine, A. Vincens, and D. Schwartz, "Phytoliths: indicators of grassland dynamics during the late Holocene in intertropical Africa," Palaeogeography, Palaeoclimatology, Palaeoecology, vol. 136, no. 1-4, pp. 213 229, 1997.

[9] J. A. Carter, "Late devonian, permian and triassic phytoliths from antarctica," Micropaleontology, vol. 45, no. 1, pp. 56-61, 1999.

[10] A. L. Carnelli, J. P. Theurillat, and M. Madella, "Phytolith types and type-frequencies in subalpine-alpine plant species of the European Alps," Review of Palaeobotany and Palynology, vol. 129, no. 1-2, pp. 39-65, 2004.

[11] L. Gallego and R. A. Distel, "Phytolith assemblages in grasses native to central Argentina," Annals of Botany, vol. 94, no. 6, pp. 865-874, 2004.

[12] D. Barboni and L. Bremond, "Phytoliths of East African grasses: an assessment of their environmental and taxonomic significance based on floristic data," Review of Palaeobotany and Palynology, vol. 158, no. 1-2, pp. 29-41, 2009.

[13] C. R. Metcalfe, Anatomy of the Monocotyledons. 1. Gramineae, Claredon Press, Oxford, UK, 1960.

[14] A. L. Ollendorf, S. C. Mulholland, and G. J. Rapp, "Phytolith analysis as a means of plant identification: arundo donax and Phragmites communis," Annals of Botany, vol. 61, no. 2, pp. 209-214, 1988.

[15] T. B. Ball, J. D. Brotherson, and J. S. Gardner, "A typological and morphometric study of variation in phytoliths from Triticum monococcum," Canadian Journal of Botany, vol. 71, pp. 1182-1192, 1993.

[16] S. S. Whang, K. Kim, and W. M. Hess, "Variation of silica bodies in leaf epidermal long cells within and among seventeen species of Oryza (Poaceae)," American Journal of Botany, vol. 85, no. 4, pp. 461-466, 1998.

[17] S. Krishnan, N. P. Samson, P. Ravichandran, D. Narasimhan, and P. Dayanandan, "Phytoliths of Indian grasses and their potential use in identification," Botanical Journal of the Linnean Society, vol. 132, no. 3, pp. 241-252, 2000.

[18] P. B. Kaufman, P. Dayanandan. Y. Takeoka, W. C. Bigelow, J. D. Jones, and R. K. Iller, "Silica in shoots of higher plants," in Silicon and Silicious Structure in Biological System, T. L. Simpson and B. E. Voliani, Eds., pp. 409-449, Springer, New York, NY, USA, 1981.

[19] L. H. P. Jones and K. A. Handreck, "Studies of silica in the oat plant-III. Uptake of silica from soils by the plant," Plant and Soil, vol. 23, no. 1, pp. 79-96, 1965.

[20] E. Blackman, "Observation on the development of the silica cells of the leaf sheath of wheat," Canadian Journal of Botany, vol. 47, pp. 827-838, 1969.

[21] J. A. Raven, "The transport and function of silica in plants," Biological Reviews of the Cambridge Philosophical Society, vol. 58, pp. 179-207, 1983.
[22] D. R. Piperno, "A comparison and differentiation of phytoliths from maize and wild grases. Use of morphological criteria," American Antiquity, vol. 49, pp. 361-383, 1984.

[23] D. M. Pearsall, K. Chandler-Ezell, and A. Chandler-Ezell, "Maize can still be identified using phytoliths: response to Rovner," Journal of Archaeological Science, vol. 31, no. 8, pp. 1029-1038, 2004.

[24] Y. Zheng, A. Matsui, and H. Fujiwara, "Phytoliths of rice detected in the neolithic sites in the valley of the Taihu Lake in China," Environmental Archaeology, vol. 8, no. 2, pp. 177183, 2003.

[25] W. D. Clayton and S. A. Renvoize, Genera Graminum, Grasses of the World, Her Majesty's Stationery Office, London, UK, 1986.

[26] M. Madella, A. Alexandre, and T. Ball, "International code for phytolith nomenclature 1.0," Phytolitharien, vol. 15, pp. 7-16, 2005. 

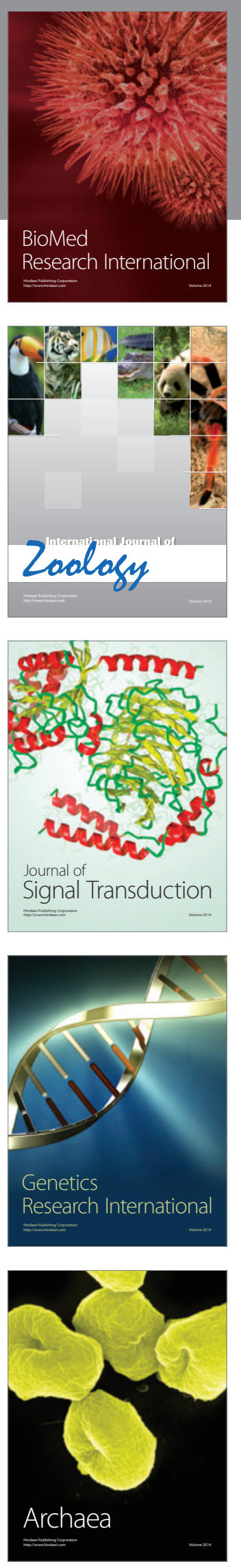
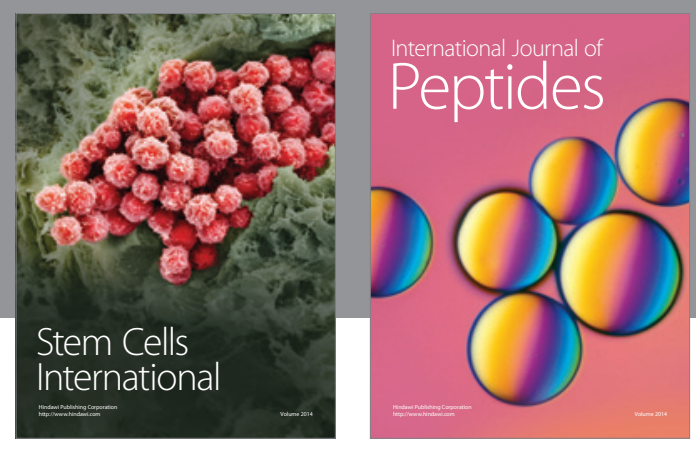

Submit your manuscripts at

http://www.hindawi.com
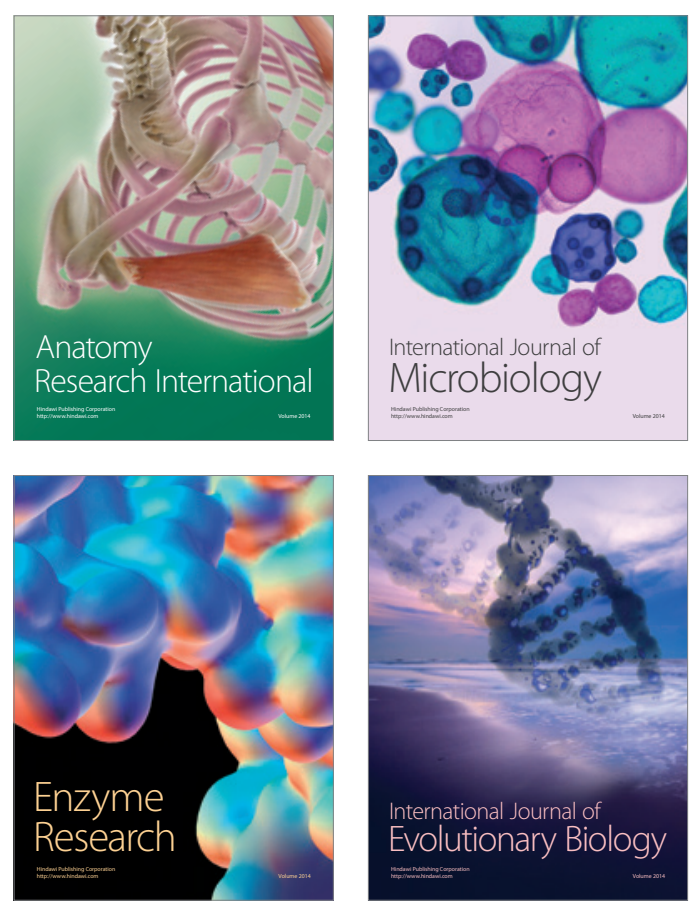
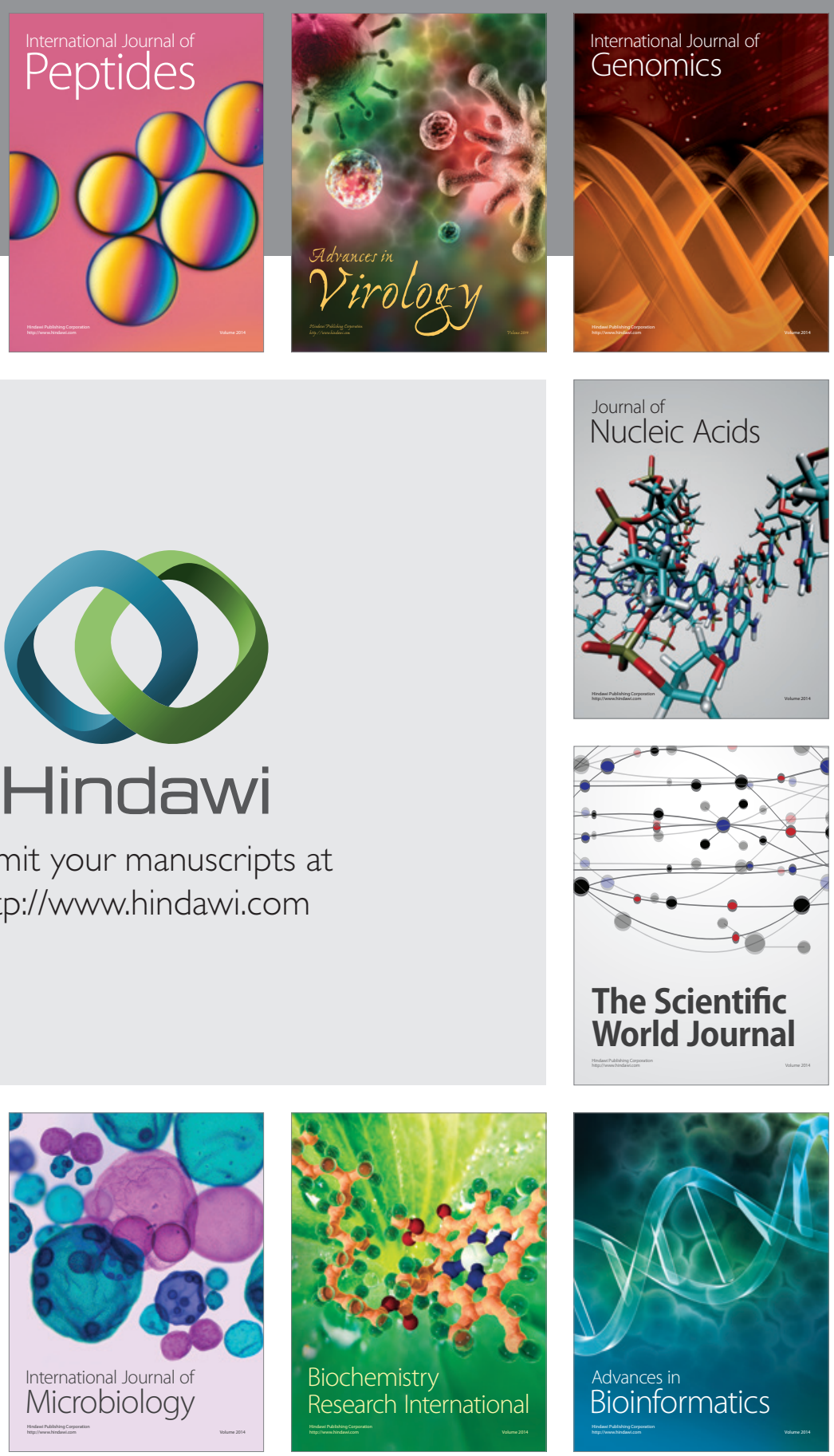

The Scientific World Journal
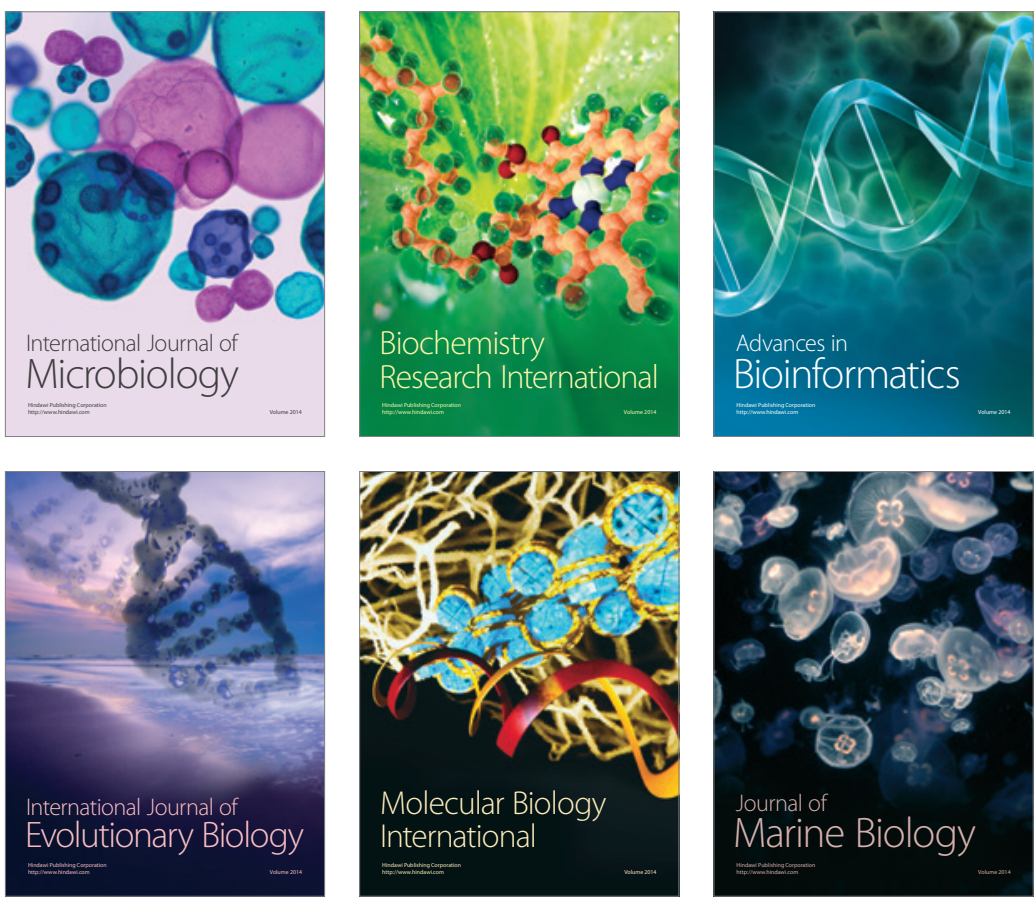